\title{
Detection of Reproductive Status in Ongole Crossbred (PO) Cow Based On Vaginal Epithel Morphology and Profile Hormone
}

\author{
Yeni Widyaningrum ${ }^{1}$, Aulanni'am Aulanni'am ${ }^{2}$, Agung Pramana Warih Marhendra ${ }^{2 *}$ \\ ${ }^{1}$ Master Program of Biology, Faculty of Mathematics and Natural Sciences, University of Brawijaya, Malang, Indonesia \\ ${ }^{2}$ Department of Biology, Faculty of Mathematics and Natural Sciences, University of Brawijaya, Malang, Indonesia
}

\begin{abstract}
Hormonal fluctuations in livestock will affect vaginal cytology good overview on the condition of estrous until pregnancy. The purpose of this study was to determine the physiological condition of Ongole crossbred (PO) cow during estrous and determine pregnancy by the description of vaginal epithelial cells, progesterone, and estrogen hormone profiles. The materials were used 35 cows with physiological status (estrous, $5^{\text {th }}$ pregnancy period, $16^{\text {th }}$ pregnancy period, $22^{\text {nd }}$ pregnancy period, and $60^{\text {th }}$ pregnancy period). Samples of Vaginal smear were stained with Giemsa, then it was observed using a microscope, with 40 times magnification. The progesterone and estrogen were analyzed by the ELISA method. The parameters measured were the percentage of vaginal epithelial cells, such as (parabasal, intermediate, and superficial) started estrous phase until the time of pregnancy in cows $(5,16,22$, and 60 days), hormone concentration, as well as the presence or absence of leukocytes. The result showed the Ongole crossbred cow estrous phase percentage of superficial cells $56.27 \% \pm 6.49$ higher than $26.23 \% \pm 7.98$ intermediate cells, followed by parabasal cells $17.50 \% \pm 4.74$. While in Ongole crossbred that were $5 \mathrm{t}^{\mathrm{h}}$ pregnancy period until the $60^{\text {th }}$ predominantly intermediate cell $80.43 \% \pm 1.31$, then the superficial cells $18.09 \% \pm 1.30$ and $1.48 \% \pm 0.04$ parabasal cells. Progesterone concentration was $63.74 \pm 1.07 \mathrm{ng} \cdot \mathrm{mL}^{-1}$ in estrus cows, and steadily increased $93.71 \pm 0.94 \mathrm{ng} . \mathrm{mL}^{-1}$ to $149.5 \pm 0.71 \mathrm{ng} \cdot \mathrm{mL}^{-1}$ in pregnant cows (5-60 days). The concentration of high estrogen levels were $122.38 \pm 0.63 \mathrm{ng} \cdot \mathrm{mL}^{-1}$ in the estrous phase, then decreased $81.54 \pm 0.44 \mathrm{ng} \cdot \mathrm{mL}^{-1}$ in the pregnancy phase. In conclusion, the concentration of hormone showed a diagnosis of pregnancy, which done by looking at changes in vaginal epithelial cells at the Ongole crossbred cow, and the cow estrous phase showed greater superficial cells compared by pregnant cows (5-60 days).
\end{abstract}

Keywords: diagnosis of pregnancy, estrous, hormone, Ongole crossbred of cow, vaginal cytology.

\section{INTRODUCTION}

The accuracy of the detection of estrous in Ongole cow is one of the critical success factors for mating success and high pregnancy rates for breeding animals. Detection of estrous in cows can be seen through animal behavior, body temperature, and external genital organs condition [1]. However, each individual of the Ongole crossbred cow can show the response changes in sexual behavior. So it is not enough to determine the appropriate time for the marriage. Mating success in livestock will be characterized by the occurrence of pregnancy. During this time, many Ongole cow repeat breeding, and also considered to be pregnant but are not parturition. Therefore, the diagnosis of pregnancy needs to know as early as possible.

Generally, pregnancy diagnosis can be determined by Rectal palpation examination and ultrasonography (USG). However, in its application of this method has two weaknesses,

\footnotetext{
* Correspondence address:

Agung Pramana Warih Marhendra

E-mail : agung_pramana@ub.ac.id

Address : Dept. Biology, University of Brawijaya, Veteran Malang, Malang 65145.
}

new rectal palpation can be performed on the $45^{\text {th }}$ day of gestation and ultrasonography on the $30^{\text {th }}$. Further, the application field assistant jobs require reproduction (ATR) experienced to ensure pregnancy [2].

Based on that condition by observing changes in vaginal epithelial cells as detection estrous cycle until the time of pregnancy. There have been many studies done using vaginal smears during the estrous cycle in sheep [3], monkeys, deer, and bears to know the estrous cycle [4]. However, little is known about this research in cows, especially Ongole cow.

According to Johnston et al. [5] on the estrous phase of vaginal epithelial cells are superficial and cornification cells. The luteal phase vaginal epithelial cells transformed into cells parabasal. It happens because of the hormonal control during the estrous phase (follicular) Gonadotropinreleasing hormone $(\mathrm{GnRH})$, which is a peptide hormone secreted by the hypothalamus tropic. $\mathrm{GnRH}$ stimulates the release of FSH and $\mathrm{LH}$ from the anterior pituitary gland. FSH stimulates the growth of follicles to produce estrogen. The luteal phase formed the corpus luteum, which produces the hormone progesterone, so that the 
endometrium is ready to accept implantation and ended in pregnancy [6]. Seeing the problems and potential in an increase in cattle reproduction Ongole cow, then we research to determine the physiological conditions that occur in estrous phase/mating properly and pregnancy diagnosis through cytological changes in vaginal epithelial cells, as well as progesterone and estrogen hormone fluctuations.

\section{MATERIAL AND METHOD}

This research conducted by farmer in the village of the district Nguling Grati, Pasuruan, and cage experiments at Beef Cattle Research, Animal Diseases Diagnostic Laboratory (ADD Lab). It started in February to April 2019.

\section{Material Research}

This study used 35 Ongole crossbred (PO) cow, which divided into five groups based on the physiological status of livestock, namely as follows. Group I cows that are not pregnant (estrous), group II pregnant cow day 5 after artificial insemination (AI), Group III to 16-day post-AI, Group IV on day 22 post-AI, and group V day 60 post-Al. The use of cows for the research was approved by the ethics committee, Brawijaya University (No. 1140-KEP-UB).

\section{Vaginal smears}

The pillowcase vaginal sample collection is done every day for one estrous cycle, that is by making a smear of the vagina. Vaginal smear was taken using sterile cotton (cotton swab) soaked with physiological saline. Subsequently, swabs smeared on glass objects until it forms a thin review and aerated. We reviewed the vaginal epithelium, which is dry, then fixed in methanol for 5 minutes. Furthermore, staining with Giemsa $10 \%$ for 45 minutes [7]. Then washed with running water and dried in air. Mixture swab examined under a microscope with a magnification of 40 times for the observation of the percentage of the number of vaginal epithelial cells.

Observations were made based on the number of 300 cells in each preparation were observed. Vaginal epithelial cells observed then calculated according to the group of each estrous cycle phase that has been determined. Criteria for determining the physiological state based on the epithelial cell shape changes (Table 1) [8].

\section{Progesterone/Estrogene Serum Measurement}

ELISA was used to measure the concentration of progesterone and estrogen serum (ng. mL ${ }^{-1}$ ). A commercial kit was used (Cusabio Technology LLc; Bioassay Technology Laboratory, Cat.No.E0240Bo). A collection of blood $10 \mathrm{~mL}$ from the jugular vein for the examination of progesterone concentrations conducted during the estrous, pregnant cow day 5 after artificial insemination, 16-day post-Al, day 22 post-Al, and day 60 post-Al. Confirmation of pregnancy by rectal palpation 45 days after Al. Serum recovered by centrifugation ( 15 minutes at 4000 $\mathrm{rpm}$ ) and stored at $-20^{\circ} \mathrm{C}$ until being assayed [9].

\section{Parameter}

The criteria phase of the estrous cycle and pregnancy is determined based on the percentage of the epithelial cell morphology picture. The diestrous phase is not formed on the cells of the superficial, proestrous phase cells are found intermediates and the percentage of superficial cells increased. Then the estrous phase of the vaginal epithelial cells formed many superficial/cornification.

Parameters measured were the percentage of the vaginal epithelium (superficial, intermediate, parabasal), the presence or absence of leukocytes cells, and the concentration of progesterone and estrogen hormone.

\section{Data Analysis}

Data were analyzed descriptively.

Table 1. Criteria for determining the physiological state based overview of the epithelial cell lines

\begin{tabular}{llc}
\hline \multicolumn{1}{c}{ Epithelial cells } & \multicolumn{1}{c}{ Epithelial cells form } & Phase \\
\hline Superficial cells & $\begin{array}{l}\text { Polygonal-shaped cells / flat without a core, } \\
\text { Cytoplasm great discount, and the edges of the } \\
\text { cell such as folding }\end{array}$ & $\begin{array}{c}\text { Estrous } \\
\text { (Follicular) }\end{array}$ \\
Intermediate cells & Large cell with a small core & $\begin{array}{c}\text { Pregnant } \\
\text { (Luteal) }\end{array}$ \\
parabasal cells & Cells are round, small and large core & $\begin{array}{c}\text { Pregnant } \\
\text { (Luteal) }\end{array}$ \\
\end{tabular}




\section{RESULT AND DISCUSSION Vaginal Epithelial Cells}

Based on observations of vaginal epithelial cells in the Ongole cow indicates that there are parabasal, superficial, and intermediates cells [10]. The observation of the vaginal smear shown in Figure 1. Percentage of epithelial cells estrous cows successively showed superficial cells $56.27 \%, 26.23 \%$ intermediate cells, and parabasal $17.50 \%$ (Table 2).

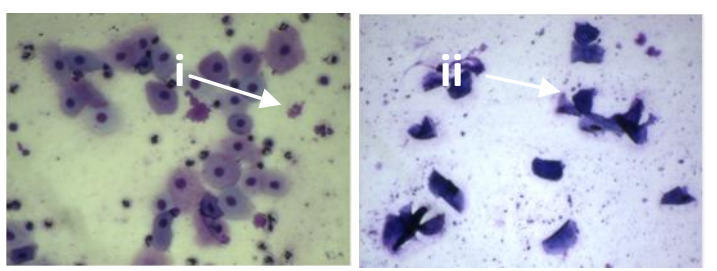

Figure 1. Cytology of vaginal swab with Giemsa staining at PO cow estrous phase (Leukocyte (i), and superficial cells (ii)

Based on the reproductive status of the estrous percentage of superficial cells are more dominant and have found their neutrophil cells. The increase in superficial cells along with higher estrogen concentration in the estrous phase is $122.38 \pm 0.63 \mathrm{ng} \cdot \mathrm{mL}^{-1}$, with the lowest concentration of progesterone $63.74 \pm 1.07$ ng. $\mathrm{mL}^{-1}$ (Fig. 3 ,
Table 1). It is consistent with previous studies Junaidi [11] that the phase of the estrous increase superficial cell and concentration of estrogen in the blood is high. The results of the previous study showed that estrogen hormone concentrations increased at the peak of estrus, which was $223.13 \pm 9.50 \mathrm{ng} \cdot \mathrm{mL}^{-1}$, then decreased in the metestrus phase $10.05 \pm 98.03$ and diestrus $67.37 \pm 8.75 \mathrm{ng} \cdot \mathrm{mL}^{-1}[9]$.

A study reported that in cow, an increase in the superficial cell of the early estrous little, medium, and then very much during peak estrous [12]. Similar results also reported by Schuttle [13] stated that the superficial cells in the vaginal swab as a specific marker by the concentration of estrogen. Superficial cells out of the basement membrane and evolved from other cells, then the cells will mature as happened cornification [14].

According to Najamudin et al. [4], when once estrus discovered, many cells form flat and do not have a nucleus is due to lysis. Core lysis of the epithelial cells happened due to keratinization to separate cells. Changes in vaginal epithelial cells are affected by the concentration of the 17- $\beta$ estradiol hormone [15]. It is because of the 17- $\beta$ estradiol receptors found in the vagina [14].

Table 2. Analysis of vaginal epithelial cytology ongole cattle in estrous phase and pregnant

\begin{tabular}{llll}
\hline \multicolumn{1}{c}{ Reproductive Status } & Superficial cells (\%) & Cells Intermediates (\%) & Parabasal cells (\%) \\
\hline Estrous phase & $56.27 \pm 6.49$ & $26.23 \pm 7.98$ & $17.50 \pm 4.73$ \\
\hline Gestation initial phase (day-5) & $41.78 \pm 0.90$ & $56.60 \pm 0.89$ & $1.62 \pm 0.31$ \\
\hline Gestation initial phase (day-16) & $42.62 \pm 0.82$ & $56.66 \pm 0.82$ & $0.72 \pm 0.69$ \\
\hline Gestation initial phase (day-22) & $22.11 \pm 4.95$ & $77.19 \pm 5.25$ & $0.70 \pm 0.68$ \\
\hline Gestation initial phase (day-60) & $18.09 \pm 1.30$ & $80.43 \pm 1.31$ & $1.48 \pm 0.04$ \\
\hline
\end{tabular}

During the estrous phase, the hormone estrogene plays an important role, which will be active in the uterus wall. It causes hypersecretion in epithelial cells of the uterus and vagina. So the superficial cells are followed by the vaginal mucosa [9]. Increasing concentrations of estrogen in the estrus phase may be related to the high percentage of superficial cells. Estrogen is a steroid hormone that is responsible for the growth and regulation of the female reproductive system and secondary sex characteristics.

The hormone estrogen is secreted by granulosa cells from de Graff follicles that are stimulated by FSH [6]. The optimal estrogen hormone causes increased activity of the uterus wall. It is resulting in uterine and vaginal epithelial cell hypersecretion and keratinization.
Therefore superficial cells were found on vaginal smear [4]. Based on Suraatmadja's research [16], the hormone estrogen also stimulated the formation of keratohyalin grains, and then it functioned as the center of intracellular filament disintegration (keratinization). Reviews of vaginal cows taken on estrus showed an increased number of cornified cells [17]. Meanwhile, in Bligon goats the percentage of superficial cells was $32.25 \%$ with estradiol concentration 247.77 pg dL [18].

The number of superficial cells in the estrous phase serves to protect the vaginal mucosa during copulation [4]. It is also characterized by a large amount of mucous secretion in the vagina. In estrus sheep, vaginal epithelial features also show the dominance of superficial cells [19]. Whereas, upon entering pregnancy, the 
dominant epithelial cells are intermediate, and no leukocytes are found (Fig. 2).

The results of vaginal examination in pregnant Ongole crossbred cow on day 5, 16, 22, and 60 obtained images of intermediate respectively $(56.60 \pm 0.89 ; \quad 56.66 \pm 0.82 ; \quad 77.19 \pm$ $5.25 ; 80.43 \pm 1.31)$, superficial $(41.78 \pm 0.90 ; 42.62$ $\pm 0.82 ; 22.11 \pm 4.95 ; 18.09 \pm 1.30$ ), and parabasal cells (1.62 $\pm 0.31 ; 0.72 \pm 0.69 ; \quad 0.70 \pm 0.68 ; 1.48 \pm$ 0.04). According to Hussain and Khan [20] in young, mid, and late pregnant cows, the dominant percentage of vaginal epithelial cells are intermediate cells $81.63 \%, 85.9 \%$, and $88.23 \%$. But with increasing gestational age, days 250 to 260 , there was a significant increase in the number of superficial cells. It is due to the activity of the hormone estrogen, due to the high concentration of the hormone progesterone [21].

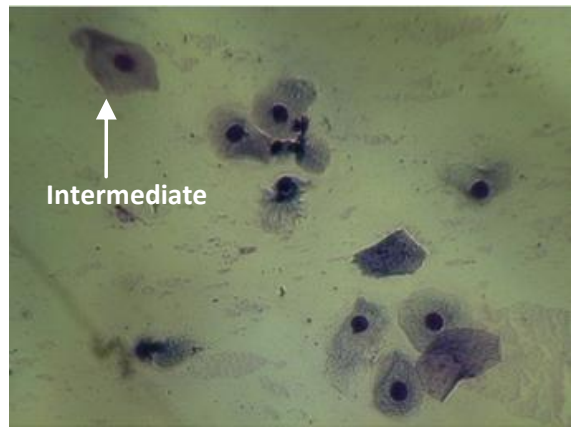

Figure 2. Intermediate cell in cows with young gestation

\section{Progesterone and Estrogen Hormone}

Based on the analysis of progesterone, the lowest concentration in the estrous phase is $63.74 \pm 1.07 \mathrm{ng} \cdot \mathrm{mL}^{-1}$, and the concentration reaches a peak in the luteal phase. In pregnant cows, the level of the hormone progesterone on the $5^{\text {th }}$ day was $93.71 \pm 0.94$ ng. $\mathrm{mL}^{-1}$, which seemed to continue to increase slowly until the gestational age was around 60 days $149.05 \pm 0.71$ ng. $\mathrm{mL}^{-1}$ (Fig. 3).

The hormone progesterone plays a role in pregnancy. The hormone progesterone produced by the corpus luteum will inhibit FSH so that no estrous back. The role of the hormone progesterone is maintaining the condition of the uterus to support a pregnancy, implantation, and fetal development [22]. The intermediate cell was found in the histology of vaginal wall epithelial cells. It indicates that the cows are in a pregnancy condition.

This result is consistent with the results of research of Ola et al. [23] a vaginal smear during pregnancy in elephant is dominated intermediate cells. Hussain [24] also reported that no leukocytes in the vaginal epithelial smear of pregnant cows. That, as well as the increasing domination of intermediate cells, can also be used as a method to diagnose pregnancy.

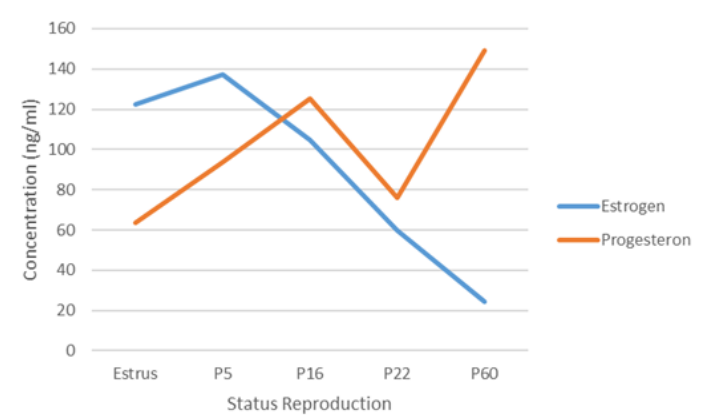

Figure 3. Progesterone and Estrogen Concentration in cows serum

\section{CONCLUSION}

Along with the hormonal analysis of estrogen and progesterone, pregnancy diagnosis can be done by looking at changes in vaginal epithelial cells of the Ongole crossbred cow. The epithelial cells dominated by intermediate cells, and in the estrous phase, Ongole crossbred cows show greater superficial cells compared to nonpregnant Ongole crossbred cow.

\section{Acknowledgement}

Thank you to the technical staff of the Indonesian Beef Cattle Research Institute (Dyah Tuwi Ramsiati, and M. Chanafi) and Mr. Nawer in conducting this research.

\section{REFERENCES}

[1] Piccione, G., G. Caola, R. Refmetti. 2003. Daily and estrus rithmicity of body temperature in domestic cattle. BMC Physiology.

[2] Lucy, M., C. Davies, T. Ott. 2007. Regulation of interferon-stimulated genes in peripheral blood leukocytes in pregnant and bred, nonpregnant dairy cows. J. Dairy Sci. 90. 274-280.

[3] Bearden, H.J., J.W. Fuquay, S.T. Willard. 2004. Applied animal reproduction, $6^{\text {th }}$ Ed. Pearson Prentice Hall. USA.

[4] Najamudin, Rusdin, Sriyanto, Amrozi, A. Srihadi, L.Y. Tuty. 2010. Penentuan siklus estrus pada kancil (Tragulus javanicus) berdasarkan perubahan sitologi vagina. Jurnal Veteriner. 11(2). 81-86.

[5] Johnston, S.D., M.R. Kustritz, P. Olson. 2001. Canine and feline theriogenology. WB Saunders comp. Philadelphia. 32-40.

[6] Julie, E.H, I. Megan. 2017. Physiology, ovulation. NCBI bookshelf. A service of the 
(Widyaningrum et al.)

National Library of Medicine, National Institutes of Health.

[7] Ahmadi, M.R., S. Naziti, H.R. Ghaisari, M. Damchy. 2006. Evaluaion of the cytology of uterus, vagina, and clitoris as predictors of uterine condition in the mare. Comp. Clin. Pathol. 14. 186-190.

[8] Nalley, W.M.M., R. Handarini, M. Rizal, R.I. Arifiantini, T.L. Yusuf, B. Purwantara. 2011. Determinaion of the estrous cycle based on vaginal sitology changed and hormon profile in Timor Hind. Jurnal Veteriner. 12. 98-106.

[9] Siregar, T.N., J. Melia, Rohaya, C,N. Thasmi, D. Masyitha, S. Wahyuni, J. Rosa, Nurhafni, B. Panjaitan, Herrialfian. 2016. Determining proportion of exfoliative vaginal cell during various stages of estrus cycle using vaginal cytology techniques in Aceh Cattle. Vet. Med. Int. Article ID 3976125. DOI: 10.1155/2016/3976125.

[10] Mayor, P., H. Galvez, D.A. Guimaraes, G.F. Lopez, M. Lopez. 2005. Serum estradiol-17â, vaginal cytology and vulval appearance as predictors of estrus cyclicity in the female collared peccary (Tayassu tajacu) from the eastern Amazon region. Anim. Reprod. Sci. 97. 165-174.

[11] Junaidi, A. 2005. Reproduksi dan obstetri pada anjing. Gadjah Mada University Press. Yogyakarta.

[12] Subramanian, A., S.R. Pattabiraman. 1988. Exfoliative vaginal cytology in bovines. Indian J. Anim. Sci. 58. 209-211.

[13] Schuttle, A.P. 2010. Technique and cytology morphology. J. Small. Anim. Pract. 18:301306.

[14] Bologna, J.W. 2001. Genitourinary problems associated with menopause. Anim. Reprod. Sci. 90. 51-55.

[15] Marcondes, F.K., F.J. Bianchi, A.P. Tanno. 2002. Determination of the estrous cyclephase of rats: some helpful considerations. J. Brazilian Archiv. Biol. Technol. 4(A). 600-614.

[16] Suraatmadja, T.O. 1982. Cornification process in the vaginal epithelium of the laboratory rat (Rattus norvegicus) under the influence of oestradiol valerate: an electron microscope study. Master Thesis. Bogor Agricultural University. Bogor.

[17] Salisbury, G.W., N.L. Vandenmark, J.R. Lodge. 1978. The reproductive system of the cow. In: physiology of reproduction and artificial insemination of catle, $2^{\text {nd }} \mathrm{Ed}$. WH.
Freeman and Company. San Fransisco. 3551.

[18] Widiyono, P.P., P. Putro, Sarmin, Astuti, C.M. Airin. 2011. Kadar estradiol dan progesteron serum, tampilan vulva dan sitologi apus vagina kambing bligon selama siklus birahi. Jurnal Veteriner. 2(4). 263-268.

[19] Solis, G., J.I. Aguilera, R.M. Rincon, R. Banuelos, C.F. Arechiga. 2008. Characterizing cytology (ECV) in ewes from $60 \mathrm{~d}$ of age through parturition. J. Anim. Sci. 82. Suppl. 1.

[20] Hussain, M.P., A.C. Khan. 1979. Exfoliative cytology and biopsy of vagina in pregnant cows. Kerala J. Vet. Sci. 10(2). 230-233.

[21] Sharma, M., N. Sharma. 2016. Vaginal cytology: an historical perspective on its diagnostic use. Adv. Anim. Vet. Sci. 4(6). 283-288.

[22] Abdullah, M., T.K. Mohanty, M. Bhakat, A. Kumaresan, T.K. Atbandha, A.R. Madkar, A.K. Mohanty. 2017. Metabolic indicators for early pregnancy in zebu and crossbred Dairy cows reared in a subtropical climate. Turk. J. Vet. Anim. Sci. 41. 407-41. DOI: 10.3906/vet-1602-10.

[23] Ola, S.I., W.A. Sanni, G. Egbunike. 2005. Exfoliative vaginal cytology during oestrus cycle of west affican dwarf goats. Reprod. Nutr. Dev. 46(1). 87-95.

[24] Hussain, A.M. 1979. Bovine uterin defence mechanism: A review. J. Vet. Med. B. 36. 641-651. DOI: 10.1111/j.14390450.1989. tb00657. 